\title{
Meine Tiertherapeuten
}

\section{Hurni}
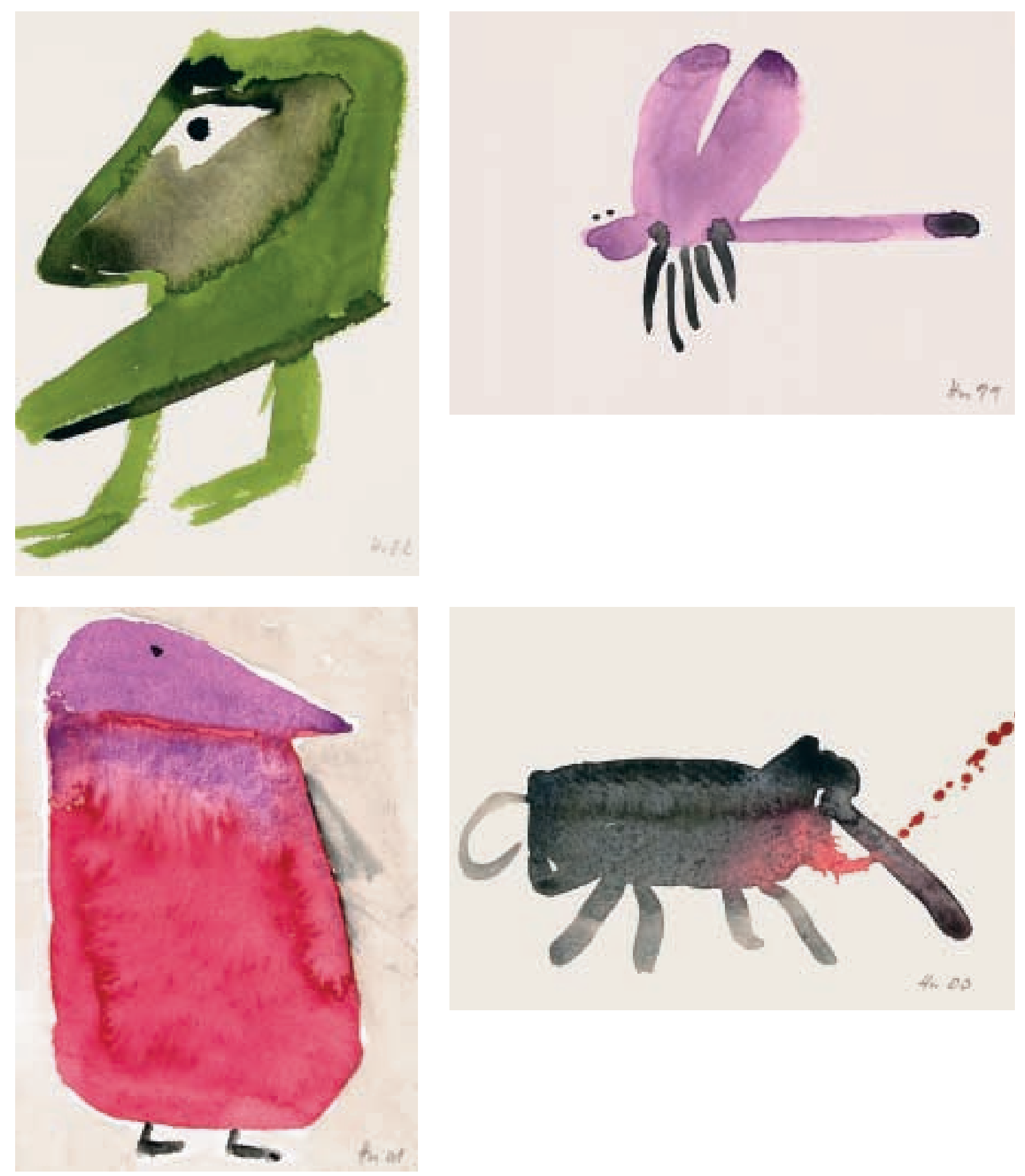

Korrespondenz: Charlotte Hurni

Forchstrasse 251

CH-8032 Zürich 

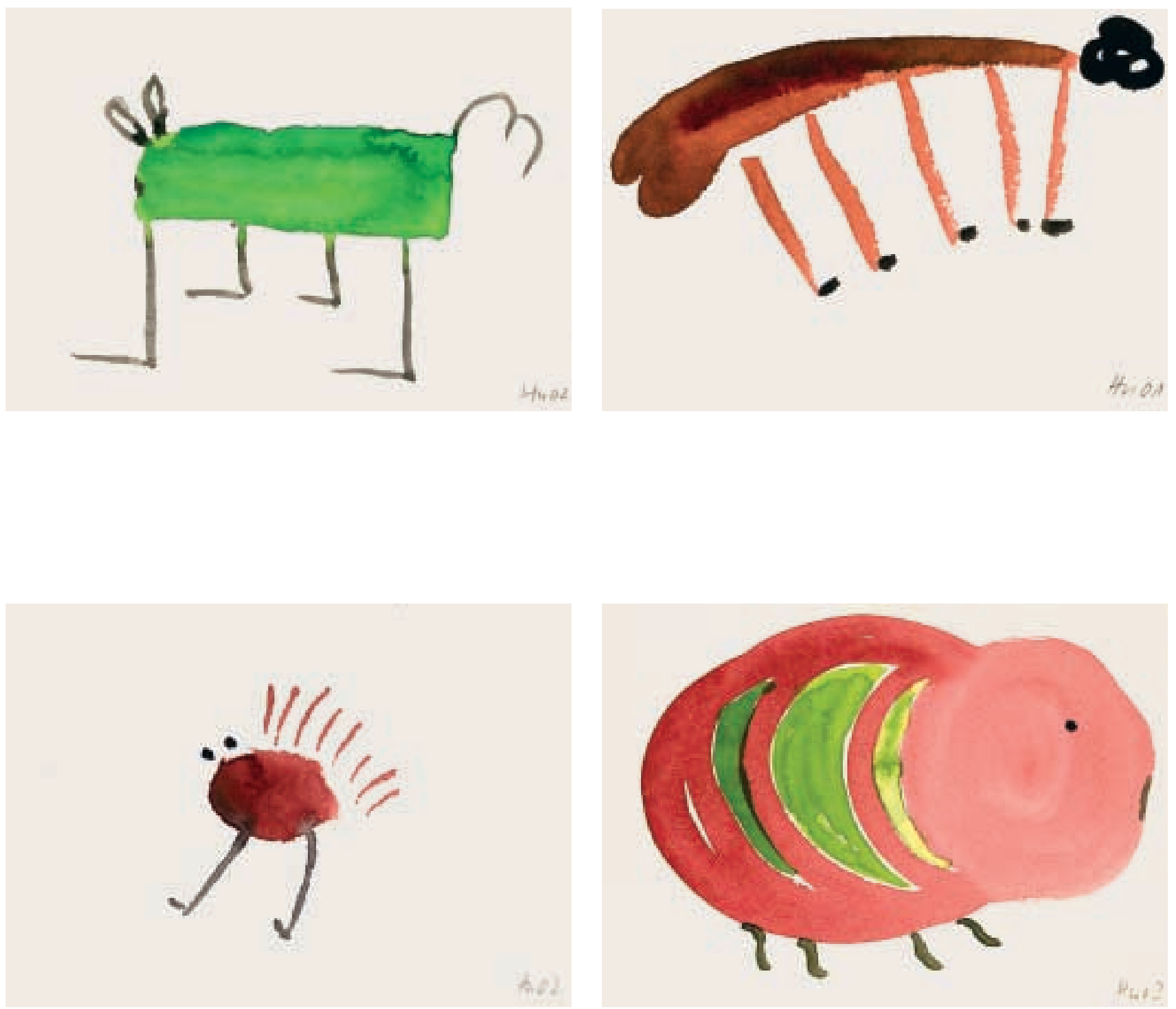